\title{
Evaluation of YKL-40 in Patients with Type II Diabetes Mellitus with Increasing Levels of Albuminuria
}

\author{
Nadia El-Menshawy ${ }^{1}$, Hanaa M Abdeen ${ }^{2}$, Maha Hamoud ${ }^{3}$, Abd- $^{4}$ \\ Elnaser Badawy ${ }^{2}$, Abd El-Hameed A Metwali ${ }^{4}$, Shahira A El-Etreby ${ }^{4}$ \\ Clinical Pathology Dept. ${ }^{1}$, Medical Biochemistry Dept. ${ }^{2}$ and Internal Medicine \\ Dept. ${ }^{4}$, Faculty of Medicine, Mansoura University, Egypt., Medical Biochemistry \\ Dept. ${ }^{3}$, Faculty of Medicine, Menoufia University, Egypt
}

\begin{abstract}
Background and Aim of work: The aim of the present study is to evaluate serum $Y K L-40$ levels in patients with type II diabetes with increasing levels of albuminuria, and to examine a possible correlation to high-sensitivity C-reactive protein (hsCRP) and insulin resistance in these patients. Methods: The study comprised 125 patients with type II diabetes attending Diabetes\& Endocrinology Unit in Mansoura Specialized Medical Hospital. They were divided into 3 groups: 39 patients had normoalbuminuria (urinary albumin excretion rate $<30 \mathrm{mg} / 24 \mathrm{~h}$ ), 46 patients had persistent microalbuminuria (urinary albumin excretion rate $30-300 \mathrm{mg} / 24 \mathrm{~h}$ ), and 40 patients had persistent macroalbuminuria/diabetic nephropathy (urinary albumin excretion rate > $300 \mathrm{mg} / 24 \mathrm{~h}$ ). The control group included 35 healthy individuals with matched age and sex. Serum YKL-40 was measured by sandwich enzyme immunoassay and serum hsCRP was measured by particle enhanced immunonephelometry. Insulin resistance was assessed using Homeostasis Model Assessment index for Insulin Resistance (HOMA-IR). Results: Mean serum YKL-40 level was $38.48 \mathrm{ng} / \mathrm{ml}, 75.33 \mathrm{ng} / \mathrm{ml}, 116.87 \mathrm{ng} / \mathrm{ml}$ and $146.43 \mathrm{ng} / \mathrm{ml}$ in control, normo- , micro- and macroalbuminuria groups respectively. Serum YKL-40 levels were significantly elevated in the three diabetic groups versus control group $(P<0.001$ for each group). Also, YKL 40 was correlated with hsCRP and HOMA-IR ( $r=0.746, P<$ $0.001 \& r=0.792, P<0.001$, respectively) in the total group of participants. ROC curve analysis showed that $Y K L-40$ is a good marker to discriminate between patients with and without albuminuria with sensitivity $93 \%$ and specificity of $88 \%$. Conclusion: It could be concluded that YKL-40, is a marker of inflammation and endothelial dysfunction. It is elevated in patients with type II diabetes with marked elevation in patients with macroalbuminuria/ nephropathy. These results suggest a role for YKL-40 in the gradually progressing vascular complications in patients with diabetes, with YKL-40 being a possible early and good marker of renal affection. It seems to be useful for screening because it is detectable in early stages and subclinical diseases.
\end{abstract}

Key words: YKL-40, type II diabetes, diabetic nephropathy, insulin resistance, hsCRP 


\section{INTRODUCTION}

Diabetes is a major health problem in the world, the micro- and macrovascular complications remain a constant challenge to the quality of life as well as increasing morbidity and mortality rate ${ }^{(1)}$. Persistent microalbuminuria is an established predictor of diabetic nephropathy leading to progressive renal insufficiency and end-stage renal disease and is associated with an increased risk of cardiovascular disease in patients with both type I and type II diabetes ${ }^{(2-4)}$.

Increasing urinary albumin excretion rate reflects vascular damage in the kidneys as part of systemic endothelial dysfunction ${ }^{(5)}$. Endothelial dysfunction is the initial step in atherogenesis, which is largely responsible for the development of ischemic heart disease and thrombotic strokes ${ }^{(6)}$.

Subclinical systemic inflammation is involved in the pathogenesis of all stages of atherosclerosis ${ }^{(7)}$. Low grade elevation of acute phase reactants, proinflammatory cytokines and cell adhesion molecules were shown to be associated with future development of myocardial infarction, stroke and peripheral vascular disease with cardiovascular mortality ${ }^{(8)}$. Several studies suggest that activation of innate immune system likely to be at least one of common antecedents of both atherosclerosis and type II diabetes. YKL-40 was reported to be a marker of inflammation and endothelial dysfunction ${ }^{(9)}$. It is produced locally at sites of inflammation, ${ }^{(\mathbf{1 0})}$ unlikely to Creactive protein produced by liver in response to IL-6 ${ }^{(11)}$.
YKL-40, a phylogenetically highly conserved heparin- and chitin-binding lectin without chitinase activity, is a member of the "mammalian chitinaselike proteins", (7, 12-14). The gene for human YKL-40 is located on chromosome 1q32.1, has a size of 7948 b.p and contains 10 exons ${ }^{(15)}$. The crystal structure of human YKL-40 protein has been described ${ }^{(16,17)}$.The protein has several names: YKL-40 ${ }^{(18)}$, human cartilage glycoprotein-39 (HC gp39) ${ }^{(7)}$, 38-kDa heparin-binding glycoprotein $(\mathrm{Gp} 38 \mathrm{k}){ }^{(\mathbf{1 3})}$, and chitinase3-like protein 1 (CHI3L1) ${ }^{(15)}$.

YKL-40 is secreted by a variety of human cells including activated neutrophils, ${ }^{(19)}$ chondrocytes, synovial cells and osteoblasts but greatest hypothesis that it is secreted from vascular smooth muscle cells (VSMCs) and macrophages ${ }^{(20,8)}$. Atherosclerotic plaque macrophages express YKL-40, particularly macrophages that have infiltrated deeper into the lesion and the highest YKL-40 mRNA expression is found in macrophages in the early atherosclerotic lesion ${ }^{(21)}$.

The full biological functions of YKL-40 are still unknown ${ }^{(22)}$. It is a growth factor for several cell types and has an established role in extracellular matrix remodeling and angiogenesis ${ }^{(9)}$. A substantial body of evidence indicates that YKL-40 participates in processes during the early stages of atherosclerosis, and it seems to be of pathogenic importance in the low-grade inflammation that precedes the development of cardiovascular disease $^{(\mathbf{9 , 1 3})}$

The participation of YKL-40 in inflammatory states and vascular processes implies that YKL-40 may be elevated in conditions with subclinical 
inflammation such as type II diabetes and insulin resistance as well as endothelial dysfunction and atherosclerosis ${ }^{(23)}$.

The objective of the present study was to evaluate serum YKL-40 levels in patients with type II diabetic patients who have increasing levels of albuminuria .Also, to examine a possible correlation to hsCRP and insulin resistance.

\section{Subjects and methods}

Using a case-control design, the diabetic participants were examined at the Diabetic \& Endocrinology Unit in Specialized Medical Hospital, Mansoura University, Egypt. The study comprised 125 patients with type II diabetes ( 66 males \& 59 females ) with age ranged from $40-$ 68 years. On the basis of 24-h urine analysis as part of the routine care of the patients, they were divided into; 39 patients with normoalbuminuria (urinary albumin excretion rate $<30$ $\mathrm{mg} / 24 \mathrm{~h}), 46$ patients with persistent microalbuminuria (at least two of three consecutive urine samples with albumin excretion rate $30-300 \mathrm{mg} / 24$ h), and 40 patients with persistent macroalbuminuria/diabetic

nephropathy (albumin excretion rate $>300 \mathrm{mg} / 24 \mathrm{~h}$ ). Diabetic retinopathy was assessed in all patients by fundus photography after pupillary dilatation and graded as nil, simplex, or proliferative. Control subjects were randomly selected from the general healthy population with matching age and sex. They had no signs or clinical symptoms of cancer, liver, metabolic, endocrinal, cardiovascular, or other systemic diseases. The study was approved by the local ethics committee. Prior to participation all patients and controls gave their informed written consent.

\section{Biochemical analysis}

Urinary albumin concentration was measured by Siemens Healthcare Diagnostics Inc., USA, from 24-h urine sample.

Eight $\mathrm{ml}$ venous blood sample was drawn, in the morning after overnight fasting (10-12 h), $7 \mathrm{ml}$ on a plain tube and serum was separated after centrifugation at $2500 \mathrm{rpm} \times$ 10 minutes, then stored frozen at $-80^{\circ} \mathrm{C}$ until analysis. One $\mathrm{ml}$ from the sample was placed on EDTA tube for $\mathrm{HbA}_{1 \mathrm{c}}$ determination (COBAS, INTEGRA, Roche Diagnostics, USA). Serum glucose and lipid profile (total cholesterol, HDL-cholesterol \& triglyceride) were measured by Siemens Healthcare Diagnostics Inc., USA. Using Dimension RXL Max clinical chemistry system (Dade Behring USA). LDL- cholesterol concentration was calculated by the Friedewald equation, $1972^{(24)}$.

Hormonal assay (insulin \& Cpeptide) was measured by electrochemiluminescence

immunoassay (Cobas, Roche Diagnostics, USA). Insulin resistance was assessed using HOMA model (Homeostasis Model Assessment index) for insulin resistance $=$ Fasting Insulin $(\mu \mathrm{U} / \mathrm{ml}) \times$ Fasting glucose $(\mathrm{mg} / \mathrm{dl}) \times 0.055 / 22.5^{(25)}$.

Serum creatinine was measured by Siemens Healthcare Diagnostics Inc., USA. Glomerular filtration rate was estimated (eGFR) using the four variable Modification of Diet in Renal Disease GFR formulas (age, sex, race, and serum creatinine) as follow: eGFR $=186 \times\left(\right.$ serum creatinine $\left.^{-1.154}\right)$ $\mathrm{x}\left(\right.$ age $\left.^{-0.203}\right) \times(0.742 \text { if female })^{(26)}$. 
Serum YKL-40 was analyzed with a commercial assay kit ((METRA, YKL-40 EIA kit, QUIDEL, USA).

Cardiophase hsCRP was estimated using an in vitro diagnostic reagent for the quantitative determination of $\mathrm{C}$-reactive protein in human serum by means of particle enhanced immunonephelometry using BN system (Dade Behring, USA).

Statistics:

The statistical analysis was performed by the SPSS 15.0 package (Statistical Package for the Social Sciences, SPSS Inc., Chicago, Illinois, USA). Unpaired student t-test was used to compare between two groups. Also, one-way ANOVA (F-test) was used to compare between more than two groups. Correlations among variables were done by spearman's correlation coefficient and linear regression analysis. ROC curve was drawn to test sensitivity and specificity. A two-sided $\mathrm{p}$ value $<0.05$ was considered significant. Qualitative data are presented as number and percent. Quantitative data are presented as mean \pm standard deviation or median (minimum - maximum) where appropriate.

\section{RESULTS}

Clinical and biochemical data for the control group and the diabetic patients differentiated according to level of albuminuria are shown in (Tables 1\&2). YKL-40 levels according to level of albuminuria are illustrated in (Fig.1). Mean YKL-40 levels were highly significantly different among all groups $(P<$ 0.001), with increasing YKL-40 levels with the increase levels of albuminuria. Moreover, pairwise comparisons showed a highly significant difference between each two groups $(P<0.001)$.

Highly significant lower eGFR was found in the micro- and macroalbuminuria groups $(P<0.001$, for each group) but no significant difference in normoalbuminuria group $(P=0.456)$ versus control group. Other pairwise comparisons showed a highly significant difference $(P<$ 0.001 ).

There was highly significant increase of serum hsCRP in all diabetic groups versus control group ( $P<0.001$, for each group), while there was no significant difference between micro- and macroalbuminuria groups $(P=0.058)$. Also, for $\mathrm{HbA}_{1 \mathrm{c}}$ there was highly significant increase in each diabetic group versus control group $(P<$ $0.001)$. No significant difference between micro- and macroalbuminuria groups was found $(P=0.469)$, there was a highly significant increase in both groups versus normoalbuminuria group $(P<$ 0.001).

For insulin resistance expressed as HOMA model there was highly significant increase in all diabetic groups versus control group $(P<$ 0.001 for each group). While, a significant difference between microand macroalbuminuria groups was found $(P=0.006)$, there was highly significant increase in both groups versus normoalbuminuria group $(P<$ $0.001)$.

There was highly significant increase of serum TG, total-C and LDL-C in each diabetic group versus control group $(P<0.001)$, but highly 
significant decrease of serum HDL-C in the three groups versus control group $(P<0.001)$.

Regarding diabetic retinopathy, there was no significant difference of YKL-40 levels between the different grades of retinopathy within each diabetic group $(P=0.053,0.391 \&$ 0.859 within normo-, micro- \& macroalbuminuria groups respectively) (Table 3 ).

Pearson's correlation between YKL 40 levels and different parameters showed correlation of YKL 40 with hsCRP and HOMA-IR $(\mathrm{r}=0.746, P<0.001 \& \mathrm{r}=0.792, P<$ 0.001 , respectively) in the total group of participants. But, this correlation was not significant in any of the different subgroups. Significant correlations of YKL-40 were also found with duration of diabetes, $\mathrm{Hb}$ $\mathrm{A}_{1 \mathrm{C}}$, eGFR (negative correlation), serum creatinine, TG, total-C, HDL-C (negative correlation), LDL-C and urinary albumin in the total group of participants (Table 4).

The changes by stepwise linear regression analysis showed that, YKL-40 levels were affected by serum TG, eGFR and hsCRP $(P$ $=0.005,<0.001 \&=0.045$ respectively), but not affected by HOMA-IR $(P=0.192)$ in the total group of participants (patients \& control).

ROC curve was done to discriminate between patients with and without albuminuria, using YKL40 as a discriminator between both groups. The results showed that, the cut off value of YKL-40 is $87.5 \mathrm{ng} / \mathrm{ml}$ (area under the curve $=0.971$ ) with sensitivity $93 \%$ and specificity $88 \%$ (Fig. 2).

Table 1: Clinical data of the control subjects and diabetic patients.

\begin{tabular}{|c|c|c|c|c|}
\hline & $\begin{array}{l}\text { Control } \\
(n=35)\end{array}$ & $\begin{array}{l}\text { Normo- } \\
\text { albuminuria } \\
(\mathbf{n}=\mathbf{3 9})\end{array}$ & $\begin{array}{l}\text { Micro- } \\
\text { albuminuria } \\
(n=46)\end{array}$ & $\begin{array}{l}\text { Macro- } \\
\text { albuminuria } \\
(\mathrm{n}=\mathbf{4 0})\end{array}$ \\
\hline Sex, Male (\%) & $19(54.3)$ & $19(48.7)$ & $23(50)$ & $24(60)$ \\
\hline Sex, Female (\%) & $16(45.7)$ & $20(51.3)$ & $23(50)$ & $16(40)$ \\
\hline Age (years) & $49.26 \pm 4.7$ & $52.46 \pm 5.55$ & $54.65 \pm 6.29$ & $57.38 \pm 5.83$ \\
\hline $\begin{array}{l}\text { Diabetes duration } \\
\text { (years) }\end{array}$ & - & $6.62 \pm 2.82$ & $10.43 \pm 2.75$ & $14.68 \pm 4.13$ \\
\hline $\begin{array}{l}\text { Retinopathy }(\%) \\
\text { None } \\
\text { Simplex } \\
\text { Proliferative }\end{array}$ & $\begin{array}{l}- \\
- \\
-\end{array}$ & $\begin{array}{l}7(17.9) \\
19(48.7) \\
13(33.3) \\
\end{array}$ & $\begin{array}{l}5(10.9) \\
19(41.3) \\
22(47.8) \\
\end{array}$ & $\begin{array}{l}4(10) \\
13(32.5) \\
23(57.5)\end{array}$ \\
\hline
\end{tabular}

Data are mean \pm SD \& number (\%). 
Table2: Biochemical data of the control subjects and diabetic patients.

\begin{tabular}{|c|c|c|c|c|c|c|}
\hline & $\begin{array}{l}\text { Control } \\
(n=35)\end{array}$ & $\begin{array}{l}\text { Normo- } \\
\text { albuminu } \\
\text { ria } \\
(\mathrm{n}=39)\end{array}$ & $\begin{array}{l}\text { Micro- } \\
\text { albuminu } \\
\text { ria } \\
(\mathrm{n}=46)\end{array}$ & $\begin{array}{l}\text { Macro- } \\
\text { albuminu } \\
\text { ria } \\
(\mathrm{n}=40)\end{array}$ & $\begin{array}{l}\text { F } \\
\text { values }\end{array}$ & $\begin{array}{l}\text { ANOVA } \\
P\end{array}$ \\
\hline $\begin{array}{l}\text { Urine albumin } \\
\text { (mg/24 hour) }\end{array}$ & - & $\begin{array}{l}19.97 \pm \\
5.44\end{array}$ & $\begin{array}{l}117.46 \pm \\
28.59\end{array}$ & $\begin{array}{l}443.33 \pm \\
100.90\end{array}$ & $\begin{array}{l}552.05 \\
1\end{array}$ & $<0.001$ \\
\hline YKL- 40 (ng/ml) & $\begin{array}{l}38.48 \pm \\
10.0\end{array}$ & $\begin{array}{l}75.33 \pm \\
16.47\end{array}$ & $\begin{array}{l}116.87 \pm \\
27.06\end{array}$ & $\begin{array}{l}146.43 \pm \\
27.74\end{array}$ & $\begin{array}{l}172.27 \\
0\end{array}$ & $<0.001$ \\
\hline Glucose (mg/dl) & $\begin{array}{l}89.29 \pm \\
10.5\end{array}$ & $\begin{array}{l}147.64 \pm \\
21.18\end{array}$ & $\begin{array}{l}222.30 \pm \\
30.10\end{array}$ & $\begin{array}{l}273.55 \pm \\
41.94\end{array}$ & $\begin{array}{l}300.22 \\
0\end{array}$ & $<0.001$ \\
\hline C.peptide (pM) & $\begin{array}{l}3.54 \pm \\
0.54\end{array}$ & $\begin{array}{l}2.20 \pm \\
0.48 \\
\end{array}$ & $\begin{array}{l}2.80 \pm \\
0.55 \\
\end{array}$ & $\begin{array}{l}3.56 \pm \\
0.57 \\
\end{array}$ & 57.918 & $<0.001$ \\
\hline Insulin (pM) & $\begin{array}{l}46.85 \pm \\
10.72 \\
\end{array}$ & $\begin{array}{l}28.36 \pm \\
6.17 \\
\end{array}$ & $\begin{array}{l}34.98 \pm \\
9.29\end{array}$ & $\begin{array}{l}63.35 \pm \\
7.55\end{array}$ & $\begin{array}{l}128.89 \\
6\end{array}$ & $<0.001$ \\
\hline HOMA-IR & $\begin{array}{l}1.31 \pm \\
0.55 \\
\end{array}$ & $\begin{array}{l}3.42 \pm \\
0.48 \\
\end{array}$ & $\begin{array}{l}5.98 \pm \\
1.62 \\
\end{array}$ & $\begin{array}{l}6.73 \pm \\
0.72 \\
\end{array}$ & $\begin{array}{l}231.43 \\
5 \\
\end{array}$ & $<0.001$ \\
\hline Total-C(mg/dl) & $\begin{array}{l}159.86 \pm \\
16.42\end{array}$ & $\begin{array}{l}227.77 \pm \\
42.61\end{array}$ & $\begin{array}{l}213.72 \pm \\
22.59\end{array}$ & $\begin{array}{l}260.95 \pm \\
51.89\end{array}$ & 49.587 & $<0.001$ \\
\hline HDL-C (mg/dl) & $\begin{array}{l}55.83 \pm \\
6.86\end{array}$ & $\begin{array}{l}45.59 \pm \\
7.64\end{array}$ & $\begin{array}{l}42.20 \pm \\
6.18\end{array}$ & $\begin{array}{l}32.98 \pm \\
3.95\end{array}$ & 84.623 & $<0.001$ \\
\hline LDL-C (mg/dl) & $\begin{array}{l}86.2 \pm \\
16.19 \\
\end{array}$ & $\begin{array}{l}114.00 \pm \\
22.40 \\
\end{array}$ & $\begin{array}{l}123.30 \pm \\
8.79\end{array}$ & $\begin{array}{l}139.03 \pm \\
15.60 \\
\end{array}$ & 69.567 & $<0.001$ \\
\hline TG (mg/dl) & $\begin{array}{l}111.97 \pm \\
19.37 \\
\end{array}$ & $\begin{array}{l}183.05 \pm \\
20.84 \\
\end{array}$ & $\begin{array}{l}210.50 \pm \\
35.59 \\
\end{array}$ & $\begin{array}{l}213.28 \pm \\
31.21 \\
\end{array}$ & $\begin{array}{l}103.79 \\
4 \\
\end{array}$ & $<0.001$ \\
\hline $\begin{array}{l}\text { Creatinine } \\
(\mathrm{mg} / \mathrm{dl})\end{array}$ & $\begin{array}{l}0.77 \pm \\
0.18 \\
\end{array}$ & $\begin{array}{l}1.04 \pm \\
0.26 \\
\end{array}$ & $\begin{array}{l}1.63 \pm \\
0.36 \\
\end{array}$ & $\begin{array}{l}1.81 \pm \\
0.32 \\
\end{array}$ & $\begin{array}{l}106.45 \\
6\end{array}$ & $<0.001$ \\
\hline $\begin{array}{l}\text { eGFR }(\mathrm{ml} / \mathrm{min} \\
\left.\text { per } 1.73 \mathrm{~m}^{2}\right)\end{array}$ & $\begin{array}{l}81.86 \pm \\
15.15 \\
\end{array}$ & $\begin{array}{l}79.90 \pm \\
5.81 \\
\end{array}$ & $\begin{array}{l}62.65 \pm \\
10.33 \\
\end{array}$ & $\begin{array}{l}47.83 \pm \\
7.65 \\
\end{array}$ & 95.736 & $<0.001$ \\
\hline hsCRP (ng/ml) & $1.91 \pm 0.8$ & $\begin{array}{l}3.31 \pm \\
0.67 \\
\end{array}$ & $\begin{array}{l}5.67 \pm \\
1.24 \\
\end{array}$ & $\begin{array}{l}6.19 \pm \\
1.27 \\
\end{array}$ & $\begin{array}{l}141.74 \\
9 \\
\end{array}$ & $<0.001$ \\
\hline HbAlc $(\%)$ & $4.5 \pm 0.9$ & $\begin{array}{l}7.18 \pm \\
0.50\end{array}$ & $\begin{array}{l}7.89 \pm \\
0.70\end{array}$ & $\begin{array}{l}8.04 \pm \\
1.04\end{array}$ & 13.932 & $<0.001$ \\
\hline
\end{tabular}

Data are mean \pm SD. HOMA-IR $>2.5$ was interpreted as impaired insulin sensitivity or insulin resistance. Significant $p:<0.05$

Table 3: Relation between YKL-40 levels and the grade of retinopathy within each group of the diabetic group.

\begin{tabular}{|l|l|l|l|l|l|}
\hline & None & Simplex & Proliferative & F & $p$ \\
\hline Normoalbuminuria & $71.6 \pm 15.8$ & $70.6 \pm 17.0$ & $84.2 \pm 13.1$ & 3.183 & 0.053 \\
\hline Microalbuminuria & $108.8 \pm 19.4$ & $112.4 \pm 28.0$ & $122.6 \pm 27.5$ & 0.961 & 0.391 \\
\hline Macroalbuminuria & $143.3 \pm 42.8$ & $149.9 \pm 26.3$ & $145.0 \pm 27.0$ & 1.101 & 0.859 \\
\hline
\end{tabular}

Data are mean $\pm S D$. Significant $p<0.05$ 
Table 4: Correlation between YKL-40 and different parameters in the total group of participants $(\mathrm{n}=160)$

\begin{tabular}{|l|l|l|}
\hline & $\begin{array}{l}\text { Correlation coefficient } \\
\mathrm{r}\end{array}$ & $P$ \\
\hline Diabetes duration & 0.562 & $<0.001$ \\
\hline Urine albumin & 0.672 & $<0.001$ \\
\hline HOMA-IR & 0.792 & $<0.001$ \\
\hline Total-C & 0.561 & $<0.001$ \\
\hline HDL-C & -0.660 & $<0.001$ \\
\hline LDL-C & 0.667 & $<0.001$ \\
\hline TG & 0.693 & $<0.001$ \\
\hline Creatinine & 0.723 & $<0.001$ \\
\hline eGFR & -0.735 & $<0.001$ \\
\hline hsCRP & 0.746 & $<0.001$ \\
\hline HbA1c & 0.305 & $<0.001$ \\
\hline Significant $P:<0.01$ & \\
\hline
\end{tabular}

Significant $p:<0.01$

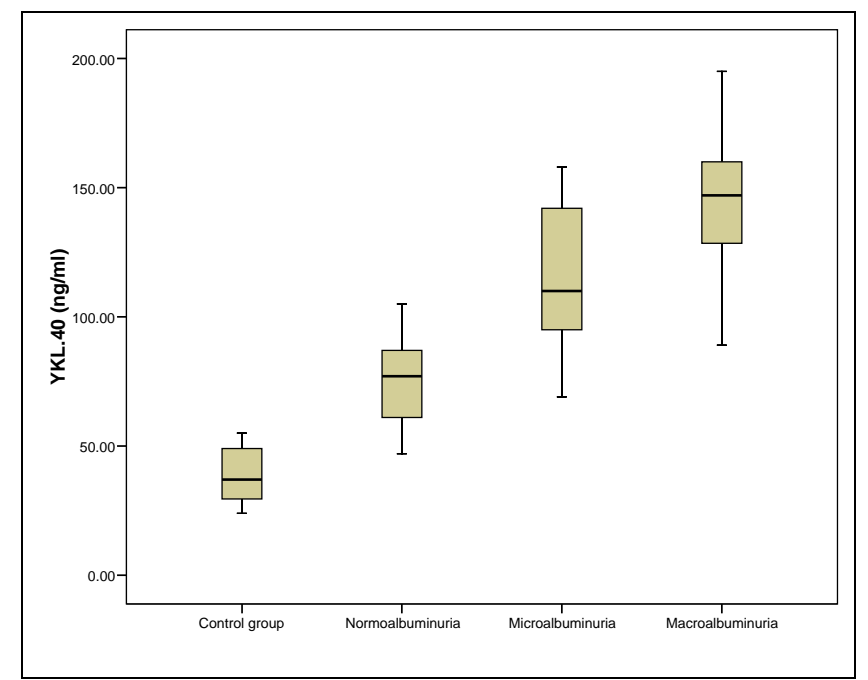

Figure 1: Median levels (minimum-maximum) of YKL-40 in the three diabetic groups compared with the control group: 37 (24-55) ng/ml in the control group, 77 (47-105) $\mathrm{ng} / \mathrm{ml}$ in the normoalbuminuria group, $110(69-158) \mathrm{ng} / \mathrm{ml}$ in the microalbuminuria group, $147(89-195) \mathrm{ng} / \mathrm{ml}$ in the macroalbuminuria group ( $p<$ 0.001 for each group Vs control group). 


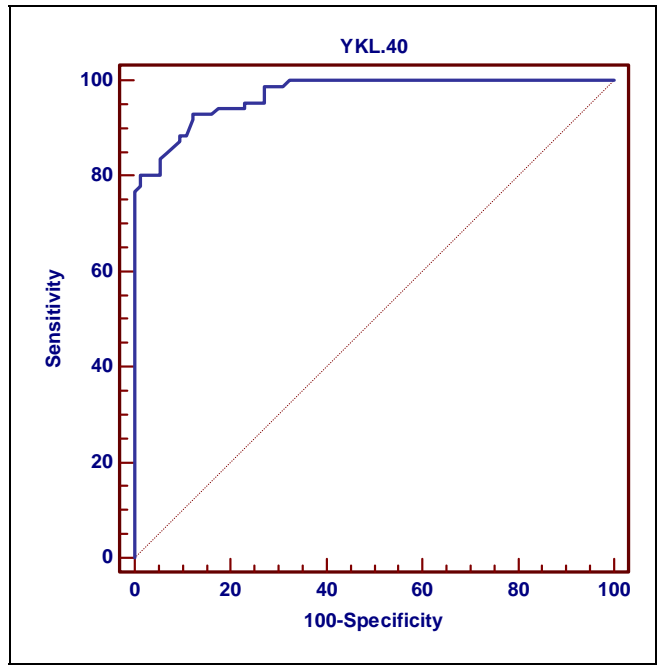

Figure 3: Roc Curve analysis to discriminate between patients with \& without albuminuria using YKL-40 as a marker. The YKL-40 criterion Value is $87.5 \mathrm{ng} / \mathrm{ml}$ (area under the curve $=0.971$ ). Ykl-40 values $>87.5 \mathrm{ng} / \mathrm{ml}$ indicate albuminuria with sensitivity $93 \%$ and specificity $88 \%$ (vice versa).

\section{DISCUSSION}

Despite improvement and intensified treatment modalities in diabetic patients, still several researches focus on more depth in the pathogenesis and complications of these patients, looking for new inflammatory markers and cytokines that enhance vascular endothelial dysfunction and its role in subclinical inflammation ${ }^{(27)}$.

YKL-40 has been regarded as an acute phase protein, since it is secreted from a variety of cells involved in infection/inflammation. The participation of YKL-40 in inflammatory states and vascular processes implies that YKL-40 may be elevated in conditions with subclinical inflammation such as type II diabetes and insulin resistance as well as endothelial dysfunction and atherosclerosis ${ }^{(23)}$.

The present study showed that serum YKL-40 levels were elevated in patients with type II diabetes compared to healthy controls, with increasing YKL-40 levels with the increase in the levels of albuminuria. This finding is in agreement with previous studies showing that chronic low-grade inflammation is associated with the occurrence and progression of (micro)albuminuria (28) and that both micro- and macroalbuminuria are accompanied by increased levels of a variety of markers of endothelial dysfunction. ${ }^{(1)}$ Also, other studies reported that patients with type II diabetes have elevated plasma YKL40 levels compared to healthy control subjects ${ }^{(23,29-32)}$.

Chronic low-grade inflammation and endothelial dysfunction seem to be closely linked, and it seems that 
chronic low-grade inflammation can be both a cause and a consequence of endothelial dysfunction. Dysfunction of the vascular endothelium is considered an important factor in the pathogenesis of diabetic micro- and macroangiopathy ${ }^{(\mathbf{1}, \mathbf{3 3})}$.

Previous studies showed that YKL-40 plays a role in endothelial dysfunction in relation to cell migration, reorganization, and tissue remodeling during atherogenesis $(\mathbf{1 3}, \mathbf{3 4}$, 35). YKL-40 promotes chemotaxis, cell attachment, spreading, and migration of vascular endothelial cells, suggesting that YKL-40 promotes the process of atherosclerotic plaque formation, in which VSMCs are induced to migrate through the intima in response to exogenous signals. YKL-40 also modulates vascular endothelial cell morphology by promoting the formation of branching tubules, indicating a role of YKL-40 in angiogenesis by stimulating the migration and reorganization of VSMCs ${ }^{(35)}$. Furthermore, YKL-40 is produced and secreted by monocytes during differentiation to macrophages and is also secreted by activated macrophages ${ }^{(9)}$. Therefore, YKL-40 seems to be a part of early stages of atherosclerosis and low grade inflammation that precedes the development of cardiovascular diseases $^{(36)}$. Immunohistochemical analysis of different types of human tissues showed high YKL-40 expression with high cellular metabolic activity and/or proliferation as fibroblast, chondrocytes \& synovial cells ${ }^{(37)}$.

Other studies suggest that YKL40 expression is an anti-inflammatory counteract of the inflammatory response mediated by tumor necrosis factor $\alpha$ (TNF- $\alpha)$ and interleukin-1 (IL-1) beside its apparent function as a growth factor. The activation of cytoplasmic signal - transduction pathways suggests that YKL-40 interacts with one or several signaling components on the plasma membrane. However, specific cell surface receptors or potential YKL-40 ligands remain to be determined ${ }^{(38)}$.Several studies have investigated the role of YKL-40 in relation to cancer but the results are still conflicting. YKL-40 levels are particularly high in recurrent cancer states and highly differentiated cancers which are characterized by high vascularization and a high turnover of extracellular $\operatorname{matrix}^{(36)}$.

In the present study, there is a significant decrease in eGFR only in diabetic patients with micro- and macroalbuminuria compared to healthy controls (diabetic patients with normoalbuminuria showed no difference in eGFR with healthy controls). This result is in harmony with other studies that found YKL-40 is associated with a decline in eGFR in diabetic patients ${ }^{(33,39,40)}$.

Diabetic nephropathy is a major manifestation of microangiopathy and is graded according to the urinary albumin excretion rate. Micro- as well as macroalbuminuria are important markers for the progression of renal dysfunction and are currently recognized as predictive factors for cardiovascular adverse events ${ }^{(\mathbf{4 1})}$. The earliest clinical evidence of nephropathy is the appearance of low but abnormal levels of albumin in the urine, referred to as microalbuminuria. Once overt nephropathy occurs the 
glomerular filtration rate gradually falls ${ }^{(\mathbf{4 2})}$. Decreases in GFR in patients with type II diabetes have been linked to increase in carotid intimal-medial thickness, carotid stiffness, and increases in the intra-renal arterial resistance index. This has led to the suggestion that the decline in GFR in type II diabetes is in part due to generalized increase in arteriosclerosis $^{(39)}$

For HOMA -IR results, the present study showed an increase in insulin resistance in patients with type II diabetes compared to healthy controls, with more increase in patients with macroalbuminuria. Also, YKL-40 was found to be correlated with HOMA-IR. This result is in agreement with previous studies which found that subclinical inflammation was strongly related to insulin resistance (HOMA-IR) ${ }^{(43,44)}$ and that in patients with type 2 diabetes plasma YKL-40 are correlated with insulin resistance ${ }^{(30)}$. Also, Rathcke et al. ${ }^{(33)}$ reported that HOMA-IR was approximately 3.5fold higher in type II diabetic patients and correlated with elevated levels of YKL-40. Generally, insulin resistance can be explained by the presence of subclinical systemic inflammation in type II diabetic patients ${ }^{(23)}$.

Also, the present study showed elevated levels of hsCRP in patients with type II diabetes compared to healthy controls, with more increase in macroalbuminuria group. This result is in agreement with previous studies that found hsCRP is increased in type II diabetic patients $(23,45,46)$. Subclinical systemic inflammation and abnormalities of a wide variety of systemic inflammatory markers have been reported in type II diabetes ${ }^{(23)}$. CRP is an acute phase response protein markedly increased in both inflammatory and infectious diseases and it also, plays an important role in innate immunity (46, 47) These observations suggest that low-grade inflammation, reflected by high serum hsCRP levels, plays a role in the induction of albuminuria, which can be considered as a risk factor of cardiovascular diseases ${ }^{(45)}$. Moreover, YKL-40 was found to be correlated with hsCRP. This is in accordance with previous studies that reported a positive correlation of elevated levels of serum YKL-40 with serum levels of CRP ${ }^{(29,48)}$. However Rathcke et al. ${ }^{(33)}$ found no correlation between hsCRP and YKL-40 in type II diabetic patients. This controversy can be explained by smaller number of diabetic patients in his study and all patients chosen in his study had no clinical or biochemical signs of diabetic complications. The perception of YKL-40 as an early inflammatory marker indicates that YKL-40 could possibly correlate with other early markers of endothelial activation and/or dysfunction \& inflammation as hsCRP ${ }^{(33)}$.

Also, in the current study marked changes in the lipid profile was found in diabetic patients in the form of increased serum $\mathrm{TG}$, total- $\mathrm{C}$ and LDL-C and decrease serum HDL-C in the three diabetic groups compared to the control group, with more dyslipidemic changes in patients with higher levels of albuminuria (macroalbuminuria).This is in accordance with previous studies which reported that diabetic patients with nephropathy have more marked 
dyslipidemias (particularly low HDL$\mathrm{C}$ and higher triglycerides) ${ }^{(49,50)}$. An established knowledge about impact role of lipid metabolism in early processing of atherosclerosis is well known. So, dyslipidemia is deleterious especially in diabetic patients ${ }^{(\mathbf{5 0})}$.

Regarding retinopathy within diabetic patients, the study did not show any association between YKL40 levels and the severity of retinopathy. This finding is in harmony with the finding of Rathcke et al. ${ }^{(33)}$ who reached the same results. Diabetic patients especially those with micro and macro albuminuria frequently had higher prevalence of retinopathy as a part of low grade inflammation, endothelial dysfunction, and high evidence of retinal arteries atherosclerotic features. Also, this insignificant association between YKL-40 and the severity of retinopathy even in macroalbuminuria group is most likely to be explained by a systemically accentuated inflammatory state minimizing the individual impact of YKL-40 ${ }^{(33)}$.

Finally, ROC curve analysis showed that, YKL-40 might be a good discriminator between patients with and without albuminuria. This is in accordance with previous studies recorded statistical significant association between YKL-40 and albuminuria in type II diabetic patients and demonstrated that serum YKL-40 level was a determinant of albuminuria independently of conventional risk factors ${ }^{(31,51)}$. YKL40 plays an important role in the process of diabetic nephropathy and atherogenesis via intermediating vascular endothelial dysfunction ${ }^{(51)}$.
Albuminuria reflects vascular damage in the kidneys as part of systemic endothelial dysfunction (5) Accordingly, serum YKL-40 level can be a good determinant of albuminuria in type II diabetic patients ${ }^{(31)}$.

In conclusion, YKL-40 has emerged as a promising marker of inflammation and endothelial dysfunction that is involved in the pathogenesis of diabetic micro- and macroangiopathy. That finding suggests a role for YKL-40 in the gradually progressing vascular complications in patients with diabetes, with YKL-40 being a possible early and good marker of renal affection. It seems to be useful for screening because it is detectable in early stages and subclinical diseases.

\section{REFERENCES}

1. Schalkwijk CG and Stehouwer CD (2005): Vascular complications in diabetes mellitus: the role of endothelial dysfunction. Clin. sci. (Lond.)., 109:143-159.

2. Borch-Johnsen K, FeldtRasmussen B, Strandgaard S, Schroll $M$ and Jensen JS (1999): Urinary albumin excretion: an independent predictor of ischemic heart disease. Arterioscler. Thromb. Vasc. Biol., 19:1992-1997.

3. Gerstein HC, Mann JF, Yi Q, Zinman B, Dinneen SF, Hoogwerf B, Halle JP, Young J, Rashkow A, Joyce C, Nawaz S and Yusuf $S$ (2001): Albuminuria and risk of cardiovascular events, death, and heart failure in diabetic and 
nondiabetic individuals. JAMA ., 286:421-426.

4. Rossing $P$, Hougaard $P$ and Parving H-H (2005): Progression of microalbuminuria in type 1diabetes: ten-year prospective observational study. Kidney Int., 68:1446-1450.

5. Deckert T, Feldt-Rasmussen B, Borch- Johnsen $\mathbf{K}$, Jensen $\mathbf{T}$ and Kofoed-Enevoldsen A (1989): Albuminuria reflects widespread vascular damage: the Steno hypothesis. Diabetologia 32:219-226.

6. Libby P, Ridker PM and Maseri A (2002): Inflammation and atherosclerosis. Circulation 105:1135-1143.

7. Hakala BE, White $\mathrm{C}$ and Recklies AD (1993): Human cartilage gp-39, a major secretory product of articular chondrocytes and synovial cells, is a mammalian member of a chitinase protein family. J. Biol. Chem., 268:25803-10.

8. Rehli M, Niller HH, Ammon C, Langmann S, Schwarzfischer L, Andreesen $R$ and Krause SW(2003): Transcriptional regulation of $\mathrm{CHI} 3 \mathrm{~L} 1$, a marker gene for late stages of macrophage differentiation. J. Biol. Chem., 278:44058-67.

9. Rathcke $\mathbf{C N}$ and Vestergaard $\mathrm{H}$ (2006): YKL-40, new inflammatory marker with relation to insulin resistance and with a role in endothelia dysfunction and atherosclerosis. Inflamm. Res., 55:221-227.

10. Ostergaard C, Johansen JS, Benfi eld $T$, Price $P A$ and Lundgren JD (2002): YKL-40 is elevated in cerebrospinal fluid from patients with purulent meningitis. Clin. Diagn. Lab. Immunol., 9:598-604.

11. Jialal I, Devaraj $S$ and Venugopal SK (2004): Creactive protein: risk marker or mediator in atherothrombosis? Hypertension 44:6-11.

12. Johansen JS, Jensen HS and Price PA (1993): A new biochemical marker for joint injury. Analysis of YKL-40 in serum and synovial fluid. Br. J. Rheumatol., 32:949-55.

13. Shackelton LM, Mann DM and Millis AJT (1995): Identification of a $38-\mathrm{kDa}$ heparin-binding glycoprotein (gp38k) I differentiating vascular smooth muscle cells as a member of a group of proteins associated with tissue remodelling. J. Biol. Chem., 270:13076-83.

14. RenkemaGH, BootRG, Au FL, Donker-Koopman WE, Strijland A, Muijsers AO, Hr Mebicek and Aerts J (1998): Chitotriosidase, a chitinase, and the 39-kDa human cartilage glycoprotein, a chitin-binding lectin, are homologues of family 18 glycosyl hydrolases secreted by human macrophages. Eur. J. Biochem., 251:504-9.

15. Rehli M, Krause SW and Andreesen R (1997): Molecular characterization of the gene for human cartilage gp-39 (CHI3L1), a member of the chitinase protein family and marker for late stages of macrophage differentiation. Genomics 43:221-5.

16. Houston DR, Recklies AD, KrupaJC and van Aalten DM (2003): Structure and ligandinduced conformational change of the 39- $\mathrm{kDa}$ glycoprotein from 
human articular chondrocytes. J. Biol. Chem., 278:30206-12.

17. Fusetti F, PijningT, Kalk KH, Bos E and Dijkstea BW (2003): Crystal structure and carbohydrate binding properties of the human cartilage glycoprotein-39. J. Biol. Chem., 278: 37753-60.

18. Johansen JS, Williamson MK, Rice JS and Price PA (1992): Identification of proteins secreted by human osteoblastic cells in culture. J. Bone. Miner. Res., 7:501-512.

19. Volck B, Price PA, Johansen JS, Sorensen O, Benfield TL, Nielsen HJ, Calafat $J$ and Borregaard N (1998): YKL-40, a mammalian member of the chitinase family, is a matrix protein of specific granules in human neutrophils. Proc. Assoc. Am. Physicians 110:351-60.

20. Krause SW, Rehli M, Kreutz M, Schwarzfischer L, Paulauskis JD and Andreesen R (1996): Differential screening identifies genetic markers of monocyte to macrophage maturation. J. Leukoc. Biol., 60:540-5.

21. Boot RG, van Achterberg TAE, van Aken BE, Renkema GH, Jacobs MJHM, Aerts JMFG and de Vries CJM (1999): Strong induction of members of the chitinase family of proteins in atherosclerosis. Chitotriosidase and human cartilage gp-39 expressed in lesion macrophages. Arterioscler. Thromb. Vasc. Biol., 19:687-694.

22. Recklies AD, White $C$ and Ling H (2002): The chitinase 3-like protein human cartilage 39 (HCgp39) stimulates proliferation of human connective-tissue cells and activates both extracellular signal-regulated kinase- and protein kinase B-mediated signaling pathways. Biochem. J., 365:119-126.

23. Rathcke CN, Johansen JS and Vestergaard H (2006): YKL-40, a biomarker of inflammation, is elevated in patients with type 2 diabetes and is related to insulin resistance. Inflamm. Res., 55:5359.

24. Friedewald WT, Levy RI and Fredrickson DS (1972): Estimation of concentration of Low-density Lipoprotein in plasma, without use of preoperative ultracentrifugation. Clin. Chem., 18:499-502.

25. Mattews DR, Hosker JP, Rudenski AS, Naylor BA, Treacher DF and Turner RC (1985): Homeostasis model assessment: insulin resistance and beta- cell function from fasting plasma glucose and insulin concentration in man. Diabetologia 28:412-419.

26. Levey AS, Bosch JP, Lewis JB, Greene $T$, Rogers $N$ and Roth DC (1999): A more accurate method to estimate glomerular filtration rate from serum creatinine: a new prediction equation modification of diet in renal disease study group. Ann. Intern. Med., 130:461-470.

27. Rossing $\mathbf{P}$, Hougaard $P$ and Parving HH (2005): Progression of microalbuminuria in type 1 diabetes: ten - year prospective observational study. Kidney Int., 68:1446-1450.

28. Jager A, Van HV, Kostense PJ, Emeis JJ, Nijpels G, Dekker JM, Heine RJ, Bouter LM and 
Stehouwer CD (2002): Creactive protein and soluble vascular cell adhesion molecule1 are associated with elevated urinary albumin excretion but do not explain its link with cardiovascular risk. Arterioscler. Thromb. Vasc. Biol. 2002., 22:593-598.

29. Rathcke CN, Raymond I, Kistorp C, Faber J and Vestergaard H (2007): The inflammation marker YKL-40 is elevated in patient with type 2 diabetes and is associated with an increased mortality rate in normal individual after adjustment for risk factor of cardiovascular events. Diabetologia 50:s103.

30. Nielsen AR, Erikstrup $C$, Johansen JS, Fischer CP, Plomgaard $P$, Krogh-Madsen R, Taudorf S, Lindegaard B and Pedersen BK (2008): Plasma YKL-40: a BMIindependent marker of type 2 diabetes. Diabetes 57:3078-3082.

31. Røndbjerg AK, Omerovic E and Vestergaard $H$ (2011): YKL-40 levels are independently associated with albuminuria in type 2 diabetes. Cardiovascular Diabetology 10:54.

32. Brix J, Höllerl F, Koppensteiner R, Schernthaner $G$ and Schernthaner G-H (2011): YKL-40 in type 2 diabetic patients with different levels of albuminuria. Eur. J.Clin. Invest., 41 (6): 589-596.

33. Rathcke CN, Persson F, Tarnow L, Rossing $P$ and Vestergaard H (2009): YKL- 40, a marker of inflammation and endothelial dysfunction, is elevated in patients with type 1 diabetes and increases with levels of albuminuria. Diabetes Care 32:323-328.

34. Millis AJ, Hoyle $M$ and Kent $L$ (1986): In vitro expression of a 38,000 dalton heparin-binding glycoprotein by morphologically differentiated smooth muscle cells. J. Cell Physiol., 127:366372

35. Malinda KM, Ponce L, Kleinman HK, Shackelton LM and Millis AJ (1999): Gp38k, a protein synthesized by vascular smooth muscle cells, stimulates directional migration of human umbilical vein endothelial cells. Exp. Cell Res., 250:168-173.

36. Johansen JS (2006): Studies on serum YKL-40 as a biomarker in diseases with inflammation, tissue remodeling, fibroses and cancer. Dan. Med. Bull., 53:172209.

37. Recklies AD, White $C$ and Ling H (2002): The chitinase 3-like protein human cartilage glycoprotein 39(HC-gp39) stimulates proliferation of human connective-tissue cells and activates both extracellular signal-regulated kinase- and protein kinase $\mathrm{B}$ mediated signaling pathways. Biochem. J., 365:119-126.

38. Ling $H$ and Recklies AD (2004): The chitinase 3-like protein human cartilage glycoprotein 39 inhibits cellular responses to the inflammatory cytokines interleukin-1 and tumor necrosis factor alpha. Biochem. J., 380:651-659.

39. MacIsaac RJ, Panagiotopoulos S, McNeil KJ, Smith TJ, Tsalmandris C, Hao $H$, Matthews PG, Thomas MC, Power DA and Jerums G 
(2006): Is nonalbuminuric renal insufficiency in type 2 diabetes related to an increase in intrarenal vascular disease? Diabetes Care 29:1560-1566.

40. Astrup AS, Tarnow L, Pietraszek L, Schalkwijk CG, Stehouwer CD, Parving $\mathrm{H}$ and Rossing $P$ (2008): Markers of endothelial dysfunction and inflammation in type 1 diabetic patients with or without diabetic nephropathy followed for 10 years: association with mortality and decline of glomerular filtration rate. Diabetes Care 31:1170-1176.

41. Nathan DM, Cleary PA, Backlund JY, Backlund J, Genuth SM, Lachin JM, Orchard TJ, Raskin $P$ and Zinman B (2005): Diabetes control and complications Trial/ Epidemiology of Diabetes Interventions and Complications (DCCT/EDIC) Study Research Group: Intensive diabetes treatment and cardiovascular disease in patients with type 1diabetes. N. Engl. J. Med., 353:2643-2653.

42. American Diabetes Association (2004): Nephropathy in Diabetes. Diabetes Care 27(suppl.1):S79S83.

43. Temelkova-Kurktschiev T, Siegert G, Bergmann S, Henekl E, Koehler C, Jaross $W$ and Hanefeld M (2002): Subclinical inflammation is strongly related to insulin resistance but not to impaired insulin secretion in a high risk population for diabetes. Metabolism 51:743-9.

44. Festa A, Hanley AJ, Tracy RP, D'Agostino R, Jr andHaffner SM (2003): Inflammation in the prediabetic state is related to increased insulin resistance rather than decreased insulin secretion. Circulation 108:1822-30.

45. Mojahedi MJ, Bonakdaran S, Hami M, Sheikhian MR, Shakeri MT, Aiatollahi H (2009): Elevated serum Creactive protein level and microalbuminuria in patients with type 2 diabetes mellitus. Iranian J. of Kidney Diseases 3(1):12-16.

46. Amanullah S, Jarari A, Govindan $M$, Basha $I$, khatheeja S (2010): Association of hs-CRP with diabetic and nondiabetic individuals. Jordan J. of Biol. Sciences 3(1):7-12.

47. Shan NN, Zhu X J , Peng J, Qin $P$, Zhuang $X W$, Wang $H C$ and Hou M (2009): Interleukin 18 and interleukin 18 binding protein in patients with idiopathic thrombocytopenic purpura. British J. Haematology 144(50):755-761

48. Matsumoto $T$ and Tsurumoto $T$ (2001): Serum YKL-40 levels in rheumatoid arthritis: correlations between clinical and laborarory parameters. Clin. Exp. Rheumatol., 19: 655-60.

49. Tuttle K (2005): The evaluation of diabetic nephropathy: preventing complications. Adv. Stud. Med., 5(1A):S20-S27.

50. Obineche ENand Adem A (2005): Update in diabetic nephropathy. Int. J. Diabetes \& Metabolism 13:1-9.

51. Festa A, D'Agostino R, Howard G, Mykkanen L, Tracy RP and Haffner SM (2000): Inflammation and microalbuminuria in nondiabetic and type 2 diabetic subjects: The Insulin Resistance 
Atherosclerosis Study. Kidney Int., 58:1703-10.

52. 52.Yasuda $T$, Kaneto $H$, Katakami N, Kuroda A, Matsuoka T, Yamasaki Y, Matsuhisa $M$ and Shimomura I (2011): YKL-40, a new biomarker of endothelial dysfunction, is independently associated with albuminuria in type 2 diabetic patients. Diabetes research and clinical practice 91(2): e50-2.

\section{تقييم مستوي ال YKL-40 في مرضي البوال السكري من النوع الثاني مع ازدياد نسبه الزيالال في البول

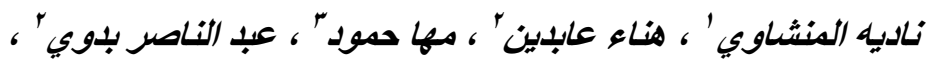

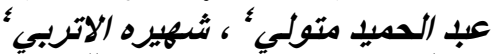

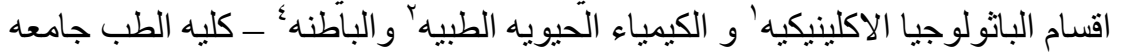

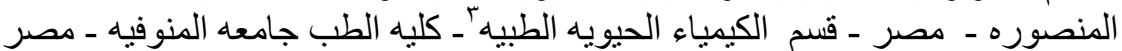

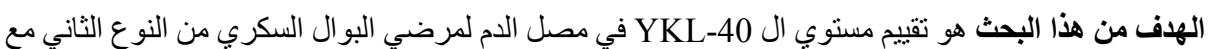

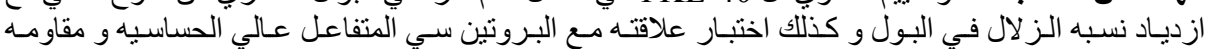

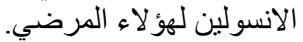

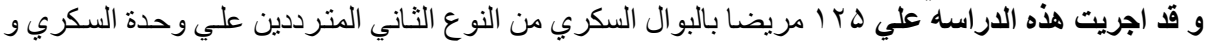

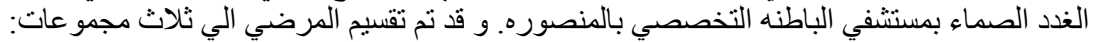

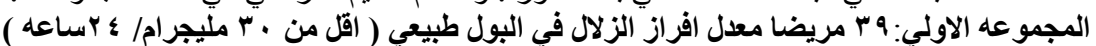

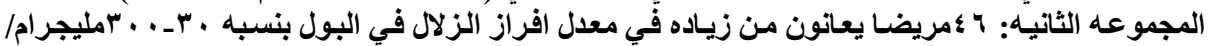

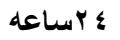

المجموعه الثالثه: · ع مريضا يعانون من زياده في معدل افراز الزلال في البول بنسبه اكثر من . . بمليجرام/

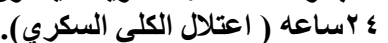

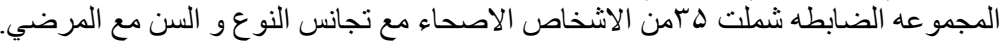

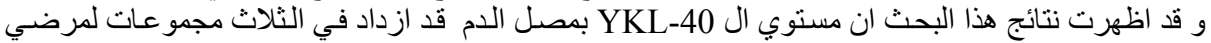

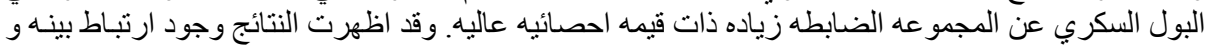

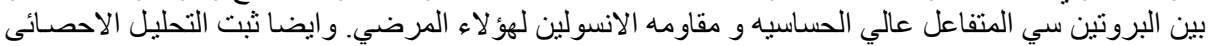

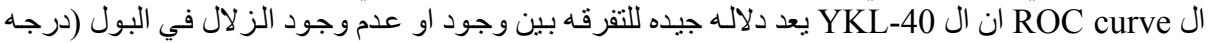

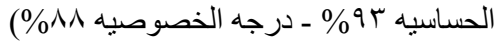

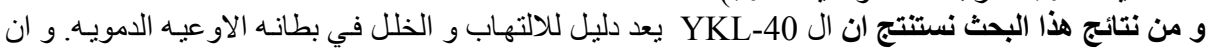

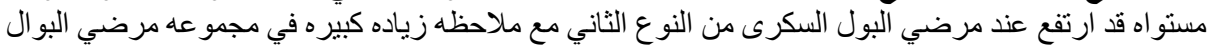

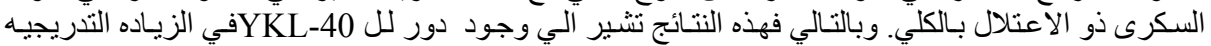

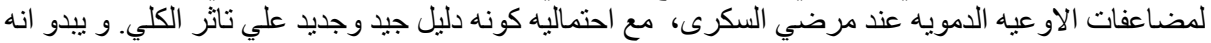
مفيد للكثف المبكر لانه يمكن قياسه في المر احل المبكرهو المرحله احته قبل الاكلينيكيه للمرض. 